\title{
THE ANALYSIS OF SPORTS AND THEIR COMMUNICATION IN THE CONTEXT OF CREATIVE INDUSTRIES
}

\author{
Stanislav DADELO (D) ${ }^{*}$ \\ Vilnius Gediminas Technical University, Faculty of Creative Industries, \\ Department of Entertainment Industries, Traku str. 1, LT-01132, Vilnius, Lithuania
}

Received 4 November 2019; accepted 14 April 2020

\begin{abstract}
The emergence of the phenomenon of sports is closely associated with the processes of communication. Sport is a social phenomenon, which solves a number of various tasks. The integrity and popularity of sport promoted the emergence and development of sport industry, integrating all human activities. The sport industry is changing with the changes in social and technologi$\mathrm{cal}$ development. It is aimed at satisfying the needs of the society at various levels (i.e. personal, group, social, national and international levels). Sport helps to solve the tasks of personal growth. The analysis of sport and the basic elements of the sport industry allows for assessing the importance and determining the stages of the sport industry's development. The phenomenon of sport and the associated industry needs a thorough study, including seemingly unrelated areas (i.e. education, physiology, psychology, law, economy, communication, culture, technologies, etc.).
\end{abstract}

Keywords: content, development, integrity of sports, interfaces, needs of the society, values.

\section{Introduction}

Sport industry is a market where people, activities, businesses and organizations are involved in producing, facilitating, promoting, or organizing any activity, experience, or a business enterprise focused on sports. It is the market where the businesses or products offered to its buyers are sport-related, and these may be goods, services, people, places, or ideas.

Sport penetrates all the segments of the social life of the society, strongly influencing the economy, as well as the relationships between the states and the political life, business, fashion, ethical values and lifestyles. It has become a major social factor, helping the people to resist bad habits and the flows of "cheap culture" products (Redner 2004; Skinner, Smith, \& Swanson, 2018). Sport has also become a powerful political tool, helping to increase the patriotism of the nation and its unity and motivates the leadership and social responsibility of citizens (Seippel et al., 2018).

The public opinion poll of physically active, particularly young, people has revealed that sport has helped them to develop their worldviews, personalities, sportsmanship, leader's

${ }^{\star}$ Corresponding author. E-mail: stanislav.dadelo@vgtu.lt 
qualities and teamwork skills, striving to win and overcome his/her weaknesses (Coakley, 2011). People with sports experience think that sport helped them gain the features of a strong personality, such as self-confidence, as well as the ability to plan and realize the goals set (Shamir \& Eilam, 2005; Fox \& Lindwall, 2014). It also helps people to develop the ability of sacrificing themselves to achieve the goal. The sporting experience gained in the youth strongly influences the behaviour of people in their whole lives. It allows people to realize that in critical situations they can rely only on themselves. All of the personal features developed by them in the period of sporting make the main factor, allowing them to stay alive in the modern world and in extreme situations (St.Pierre, Hofinger, \& Simon, 2016). Since the phenomenon of sports has a social basis, it is in the centre of the social sciences' research. Sporting activities promote the development of interrelations and communication between people. The objective evaluation of the importance of sport requires not only the knowledge of the form and content of sport activities, but also the awareness of the social needs, motives and relationships, making the basis of the formation of personalities, social groups, communities and nations. Sport as a phenomenon is not homogeneous. It has various segments and their structures, functions, stages of development and relationships with social life (political, economic, social, cultural and spiritual). Considering the social aspect of sport, such problems as its historical development, the laws governing its functioning in society and the influence on the society's and people's socialization processes and the relationships with other areas of life (Jones 2014) should be analysed. From the theoretical and methodological perspectives, the sports science is integral, considering the historical development of physical education, sport psychology, as well as its physiological aspects, because a personality is formed under the influence of both social and physiological factors (Dadelo, 2013).

\section{The phenomenon of sport}

In recent years, various dynamic changes have taken place, concerning a revision of sport values and their influence on the modern society. Sport as a social phenomenon is changing its functions and tasks in the society, which presents new challenges to the sport phenomenon and promotes changes in sport values. Finally, social changes in sports contribute to changing the forms of social behaviour and ways of life, as well as the content and aims of sporting activities. The increasing role of sport in social life causes the global sport commercialization.

Commercialization of sport turns it into a business instrument (Margaritis, 2019). Sporting activities and their content are often based on the interests of the sporting event's organiser, getting the highest profit, rather than on the interests of sport consumers (sportsmen and spectators), such as achieving the best result or watching an attractive performance). Professionalization of sport increases the results achieved by the sportsmen, causing them to break away from the mass sporting movement and making them unattainable by ordinary citizens. These trends help to change the content and values of sports. The information officially spread by sports organizations claims that sport is based on the mass character. It unites the members of the society and is a source of their health and harmony. However, a sceptical attitude to professional sports is getting popular. More negative features of professional sports, such as its inhumane character and lack of aesthetics, become known to 
people. These features are associated with the growing competition, doping, aggressiveness and even cruelty. The hostility of athletes and spectators manifests itself not only during competitions, but also elsewhere. Sport often acquires a consumerist character and loses the real sport values. To increase the formation of a positive sport image the organizers should promote the humanistic ideals of sports. If the negative image of sports persists, the negative evaluation of sports by the society will increase. Therefore, sports policy at the state and the international levels should be revised. The need for sporting activities is growing to satisfy the needs and interests of people (e.g. health, beauty, workability, humanism, active and rich leisure time, etc.). The politicians striving to satisfy the social needs are creating the policy based on the mass character of sports, where all members of society are involved in sporting activities. The sport organizations of the world proclaim the main aim of the Olympic Movement - the unity of sport, culture and art at the national and international levels (Hoekman, Schulenkorf, \& Welty Peachey, 2019).

The standards of living of people are changing and, therefore, the requirements of people to sports are also being changed. The global changes can be observed in the principles and methods of sport functioning. Individual consumers, social groups, communities, states and international organizations set new requirements to sport. Sport is used to promote the democratic changes in the society (Asle Bergsgard et al., 2019). However, a general policy model of sports is found only in the part of the social democratic welfare regimes (Bergsgard \& Norberg, 2010) and is a universal welfare good in sports, which aims at including the entire population, regardless of organizational affiliation, as the material basis for reaching the goal of sport for all. The prevalence of sports in society shows the level of the state's democracy and the welfare level of the community (Seippel, 2017). One of the most important indicators of the prevalence of sports is the material basis for reaching the goal of sports for all, which is well in line with the social democratic welfare regime (Sowell, 1995).

Thus, the phenomenon of sports strongly influences social development and, therefore, requires more attention and a thorough analysis. Great dynamic changes take place in the world, which are difficult to predict and to evaluate. To better understand the phenomenon of sports and to evaluate its effect on the development of a cohesive society it is important to identify the content of this phenomenon and to define it. This would allow sports to penetrate other areas of life. The definition of the concept of sports would form a prerequisite to evaluating its effect on human activities and a personality and determining their relationship.

\section{Sport definitions}

The global expansion of sporting activities created a wide range of new activities advertised as sports. There are sport experts who maintain that the basic integrity of sports is undermined by the expanding definition. Therefore, at the beginning, it is necessary to consider the concept of sports and what activities constitute "sport". At the global level, there are no experts' sources of sports to provide a definitive answer to the sports definition. There are some differences in sports definitions found in the legal documents regulating the activities of people in the field of sports and in the scientific works of experts from various areas. 
In the report of the "United Nations Inter-Agency Task Force on Sport for Development and Peace" (2003) the term "sport" covers all forms of physical activities that promote good physical fitness, mental well-being and social interaction. There, the definition of sports involves games, entertainment, recreational or competitive sporting events, as well as sports and traditional games. The definition of sports as described by the Council of Europe, Committee of Ministers (2001) is

"all forms of physical activity which, through random or organized participation, are directed towards the expression or improvement of physical and mental well-being, formation of social relations or achievement of results in competitions of all levels".

The problem of the proper definition of the concept of sports is associated with the nature of sports, i.e. the competition activity. The modern definition of "sports" describes the activities and games that have become a competitive race between teams or individuals and are highly appreciated by the public (Shilling, 2005). The attempt to introduce a comprehensive definition of the term "sports" proved to be difficult (Jarvie, Thornton, \& Mackie, 2018). The phenomenon of sports covers various types of physical activities where the participants demonstrated the event based on the principle of fair play and specific sports ethics (Darnell et al., 2018).

Generally, sports include all types of competitive physical and mental activities and games (Sport Accord, 2010). The immediate aim of sports is using, maintaining or improving physical ability and skills while providing enjoyment to participants, and in some cases, entertainment for spectators (Council of Europe, Committee of Ministers, 2001). Sports includes many activities involving single contestants and hundreds of simultaneous participants, as well as teams. It is essential to have a general, scientifically sound definition and to clearly understand the description of activities that could be considered as sports.

Various kinds of sports within the Sport Accord (2010) are classified in the categories given below:

1. Physical;

2. Mind;

3. Motorised;

4. Coordination;

5. Animal-supported.

Sports is influenced by social processes and, therefore, is constantly changing. There is an intense competition not only among the sportsmen, but among various types of sports as well because they are competing to get more fans and to attract spectators and sponsors. This is a dynamic process. The international sports organizations take into account the changing social needs and support the emergence of new sports.

Sport Accord (2010) uses the following definitions to describe new sport directions:

1. The sport proposed should have an element of competition;

2. The sport proposed should in no way be harmful to any living creatures;

3. The sport should not rely on equipment that is provided by a single supplier;

4. The sport should not rely on any "luck" element specifically designed into the sport. 
Though old kinds of sports, having a great number of supporters, dominate in the world, new kinds of sports are appearing every year. They gain popularity and create a separate genre. New sports are fast gaining popularity across the world and paving new opportunities for the young generation (Ratten, 2019).

The changes in sports take place simultaneously with social development. Socioeconomic development not only promotes structural changes in sports, but also changes the values formed by sports, creating new standards of behaviour and lifestyles. The social changes caused by sports make the basis of modern culture. Modern processes taking place in sports form new social, cultural and structural models, organizations and groups related to sports. The effect of sports on social development is complex because both social and economic effects are produced. Sport-related processes promote the creation of an independent sport industry.

\section{Sport industry and its structure}

Social, technological and economic changes taking place in the society have formed the concept of leisure and entertainment, combining culture and consumption. The consumer market is usually achieved through the industry of entertainment by using advertising and mass media technologies. The consumer goods of the market are associated not only with their usefulness for consumers but also with pleasure and entertainment. Entertainment makes an inherent part of the life of modern society and its importance has been constantly growing in recent years in all the areas. Sport as an important part of entertainment combines the markets of producers and consumers into a specific sport industry, which embraces the markets functioning according to the economic laws and generates goods, services, the environment and ideas oriented to sports activities and strengthening of the body (human health, satisfying the specific body's needs in sports and in professional and everyday activities) and leisure (Ozturk, 2014).

Sport industry forms specific communicative and economic relations. Sport as a kind of specific activities, economics and industry also creates jobs. A business taking part in the sporting process creates jobs, profit, increases the flow of taxes to the budget and creates the society of a new kind, helping to solve some important social problems. The growth of the sport industry is closely associated with economic and industrial development (i.e. industry, trade, services, construction, education, etc.).

Sport industry has been created based on sporting activities and is expanding them. This has become an important factor in social development because sport industry combines various types of activities and unites the participants having various motives, aims, tasks and activities. There are no statistically average consumers and producers of sport industry. As any other activity, sport industry needs the identification of the specific features of the activities and their consumers. This is required for segmenting sport industry into the particular elements and their groups (segments).

The market of sport consumers is segmented based on their mentality, reflecting the relationship between rationality and emotionality. The segmentation of the market of the sports product suppliers is required for providing their consumers with the products possessing the 
properties which could satisfy their psychological and physiological needs through consumption and participation (Sohn, Canbolat, \& Gardner, 2017). At the same time, the sociological data on the consumers (i.e. sex, age, education, income, etc.) can help understand their choice and group them according to their motives and behaviour (Yousaf, Bashir, \& Mishra, 2020; Trail \& James, 2001).

The segmentation of sport industry allows for identifying the needs of the consumers and converting them into demands. Segmentation means the division of the producers' and consumers' market into the smaller and clearly outlined segments with similar features. It is important to identify and evaluate the particular features and motives of the sport consumers when their typological portraits are created (Rohm, Milne, \& McDonald, 2006). Typological studies and segmentation of sport consumers help to achieve effective communication between the producers of sports products and their consumers (Trail, Fink, \& Anderson, 2003). The segmentation of the sports market al.ows for predicting the trends of the sport's development and expansion, as well as optimizing the communication among the producers and consumers of the sports products. The formation of the sport industry's markets is dynamic and, therefore, needs constant re-evaluation. The origin of the segmentation of the sport industry is associated with the work of Pitts, Fielding, and Miller (1994), who divided the sports market as follows:

1. sport performance (which includes the consumption of sport through spectation and participation);

2. sport production (which includes the products and services needed for the production of sports activities);

3. sport promotion (which includes sponsorship, endorsements, merchandising, and sport media).

A large number of ways and methods of market segmentation have been created. This is a dynamic process, depending on the state of the market, which in turn, depends on social, economic and technological development. The participants of the sport industry are competing for customers in creating new market segments. The segmentation of the sport industry's market mainly depends on the identification of the consumers' needs, seeking to turn the market of the sports products' producers into the demand. The generation of new segments of the sport industry's markets and their expansion can be achieved only by developing intense communication among the participants of the market.

\section{Sport industry's communication}

The collection and the analysis of information about the choices of market participants for the products' suppliers allows for understanding the choices of their consumers. The attention of consumers to the products offered on the market is becoming one of the most important sources of the collected information, on which the communication guidelines are based. Now, social communication of market participants is being transferred to the electronic realm. The collection and processing of the information about market participants and the generation of the content of communications aimed at various market segments are 
more often turned over to the specialized software having artificial intelligence (Milgrom \& Tadelis, 2018). Only the interaction between the artificial and the human intellects allows us to make effective communication solutions of better quality (Lichtenthaler, 2018; Plastino \& Purdy, 2018).

Sport communication embraces the interpersonal and interorganizational levels in various kinds of sports and among them. The aims of sport communication may be associated with the demonstration of the use of the products and the presentation of their peculiarities to consumers. To achieve these aims marketing technologies are used. To describe the sports marketing communication a definition presented by Fill (2009) may be used, which describes it as a controlled process when the supplying organization begins a dialogue with its target audience. In this way, the supplier of the product prepares and transmits the information aimed at the interested group of people, as well as evaluating the feedback and continuing the communication process based on it. The aim of communication is the positioning of the product or its supplier and its correction to influence the target group of people. The whole process is aimed at forming the evaluation level and the behaviour of the target group.

Sport communication is getting a greater attention in the research works, where mass media and sport consumption are the dominant topics (Pedersen, 2013). Sport industry's development is acquiring a global scope, penetrating all social activities and involving specialists in various fields (e.g. trade, management, law, marketing, entertainment, finance, production, high technologies, etc.). Sport industry has achieved all the scopes of social activities (i.e. interpersonal, social, self-governmental, state and international) both at the amateur and professional levels. Sport industry promotes the communicative relations, combining its branches into a united economic power. The communicative relations between all the processes of the sport industry make it powerful. Communication is becoming the main factor of the sport industry's development (Romney \& Johnson, 2020). The integrity of the sport industry makes sport communication a powerful tool, influencing the choices of the community and the marketing and management processes in various areas (Stoldt, Dittmore, \& Branvold, 2012). Sport cannot exist without communication, which is a catalyst of the sport industry's development. The researchers emphasize that the processes of sport communication are being accelerated and this tendency is stable (Wheaton \& Thorpe, 2019).

New social media technologies are assessed in sport industry as a rapidly developing segment of sport communication. People going (or not going) in for sports or organizations associated with it, who are striving to socialize, pay more and more attention to the segment of social media (Naraine, Wear, \& Whitburn, 2019). The technological advance allows the sport industry's communication to reach a larger audience and to spread the information, quickly reacting to social changes, as well as maintaining close relations with the existing consumers and increasing their number. New technologies have largely widened the spectre of the methods used in sport communication and created the attractive realm of communication for achieving various purposes. Taking into account the effect of sport communication on all human activities, it can be considered a powerful strategic tool, which requires the collection of the research data, their generalization and systemization. 


\section{The relationships between sport and creative industries}

Tkaczyk and Krzyżanowska (2013) and Mumford (2019) emphasize that creative industries are considered to be the most rapidly developing branch of industry, which provides great possibilities for the development in all human activities. Therefore, creative industries are considered to be one of the areas, generating the largest amount of jobs, thereby contributing to social welfare, as well as promoting consumption and services, increasing social stability and promoting international development (Howkins, 2013). Creative industries, as well as the sport industry, are based on integrity and adaptability to the social processes in the society (Memmert, 2016). It is necessary to constantly revise the relationships between sport and creative industries and their integrity. Sport and creative industries are most closely interrelated in the areas of innovations and businesses (DiMaggio, 2003). Their relationship needs re-evaluation. It is necessary to clearly determine the integration processes of sport and creative industries and to evaluate their scope and intensity. The integrative processes of sport and creative industries have shown that their theoretical and scientific basis is lagging behind the real life. To achieve that science would play the role of the "catalyst" and promote positive local and global changes in the society the processes taking place in science and the society, as well as their communication, should be constantly observed and investigated.

\section{Conclusions}

Sport performs the function of human socialization by using various methods at various levels (e.g. personal, group, community, national and international relations). Sports is closely associated with communication processes required for its existence. The communicative aspect of sports promotes its penetration into all spheres of human activities. The cultural and economic expansion of sport communication has promoted the emergence of the sport industry, which became an important factor in combining the economic, cultural, industrial, technological and scientific aspects. Sport industry not only generates large-scale revenues, but also is an important part of the cultural life of society. Though sport is associated with the mass character, a healthy way of life and humanistic values, its commercialization caused some negative effects (e.g. the signs of aggression and nationalism, doping scandals, isolation of sportsmen). Now, sport experiences the changes in values and goals caused by the global social changes. Sport has changed from the source of entertainment and spending the leisure time into the inherent part of the modern urban life of the people. The changes taking place in sport's content and goals cause the growth of its relationships with the creative processes, which promotes stronger integration of the creative and sport industries. Sport industry is changing dynamically, and its influence on the society is growing. Sport has become a phenomenon promoting the communication processes, as well as social, economic and technological development. The integral character of sport determines its dynamic change. Therefore, the segmentation of the sport industry should be made periodically, taking into consideration the trends of the changes. 


\section{References}

Asle Bergsgard, N., Borodulin, K., Fahlen, J., Høyer-Kruse, J., \& Bundgård Iversen, E. (2019). National structures for building and managing sport facilities: a comparative analysis of the Nordic Countries. Sport in Society, 22(4), 525-539. https://doi.org/10.1080/17430437.2017.1389023

Asle Bergsgard, N., \& Norberg, J. R. (2010). Sports policy and politics - the Scandinavian way. Sport in Society, 13(4), 567-582. https://doi.org/10.1080/17430431003616191

Coakley, J. (2011). Youth sports: what counts as "positive development?" Journal of Sport and Social Issues, 35(3), 306-324. https://doi.org/10.1177/0193723511417311

Council of Europe, Committee of Ministers. (2001). Recommendation No. R (92) 13 Rev. of the Committee of Ministers to Member States on the Revised European Sports Charter (Adopted by the Committee of Ministers on 24 September 1992 at the 480th Meeting of the Ministers' Deputies and Revised at Their 752nd Meeting on 16 May 2001). https://search.coe.int/cm/Pages/result_details. aspx?ObjectID $=09000016804 \mathrm{c} 9 \mathrm{dbb}$

Dadelo, S. (2013). Kūno kultūros ir sporto mokslo plètros aktualumas tarpdalykinių komunikaciju kontekste. Santalka: filosofija, komunikacija, 21(1), 55-64. https://doi.org/10.3846/cpc.2013.06

Darnell, S. C., Chawansky, M., Marchesseault, D., Holmes, M., \& Hayhurst, L. (2018). The state of play: critical sociological insights into recent "Sport for Development and Peace" research. International Review for the Sociology of Sport, 53(2), 133-151. https://doi.org/10.1177/1012690216646762

DiMaggio, P. (2003). David Throsby: 2001. Economics and culture (Book Review). Journal of Cultural Economics, 27, 73-75. https://doi.org/10.1023/A:1021567916234

Fill, Ch. (2009). Marketing communications: interactivity, communities and content. Pearson Education Limited.

Fox, K. R., \& Lindwall, M. (2014). Self-esteem, self-perceptions and exercise. in A. Papaioannou \& D. Hackfort (Eds.), Routledge companion to sport and exercise psychology (pp. 34-48). Series: International Perspectives on Key Issues in Sport and Exercise Psychology. Routledge.

Hoekman, M. J., Schulenkorf, N., \& Welty Peachey, J. (2019). Re-Engaging local youth for sustainable sport-for-development. Sport Management Review, 22(5), 613-625. https://doi.org/10.1016/j.smr.2018.09.001

Howkins, J. (2013). The creative economy: how people make money from ideas. Penguin Books.

Jarvie, G., Thornton, J., \& Mackie, H. (2018). Sport, culture and society: an introduction. Routledge. https://doi.org/10.4324/9781315688961

Jones, I. (2014). Research methods for sports studies. Routledge.

Lichtenthaler, U. (2018). Substitute or synthesis: the interplay between human and artificial intelligence. Research-Technology Management, 61(5), 12-14. https://doi.org/10.1080/08956308.2018.1495962

Margaritis, K. (2019). Law, ethics, and integrity in the sports industry. Series: Premier Reference Source. IGI Global. https://doi.org/10.4018/978-1-5225-5387-8

Memmert, D. (2016). Teaching tactical creativity in sport: research and practice. Series: Routledge Studies in Physical Education and Youth Sport. Routledge. https://doi.org/10.4324/9781315797618

Milgrom, P. R., \& Tadelis, S. (2018). How artificial intelligence and machine learning can impact market design. NBER Working Paper No. 24282. Series: NBER Working Paper Series. https://www.nber.org/papers/w24282.pdf

Mumford, S. (2019). The aesthetics of sport and the arts: competing and complementary. Sport in Society, 22(5), 723-733. https://doi.org/10.1080/17430437.2018.1430478

Naraine, M. L., Wear, H. T., \& Whitburn, D. J. (2019). User engagement from within the Twitter community of professional sport organizations. Managing Sport and Leisure, 24(5), 275-293.

https://doi.org/10.1080/23750472.2019.1630665 
Ozturk, R. G. (Ed.). (2014). Handbook of research on the impact of culture and society on the entertainment industry. IGI Global. https://doi.org/10.4018/978-1-4666-6190-5

Pedersen, P. M. (2013). Reflections on communication and sport: on strategic communication and management. Communication and Sport, 1(1-2), 55-67. https://doi.org/10.1177/2167479512466655

Plastino, E., \& Purdy, M. (2018). Game changing value from artificial intelligence: eight strategies. Strategy and Leadership, 46(1), 16-22. https://doi.org/10.1108/SL-11-2017-0106

Pitts, B. G., Fielding, L. W., \& Miller, L. K. (1994). Industry segmentation theory and the sport industry: developing a sport industry segment model. Sport Marketing Quarterly, 3(1), 15-24.

Ratten, V. (2019). Sports, technology and innovation: assessing cultural and social factors. Springer Nature Switzerland AG. https://doi.org/10.1007/978-3-319-75046-0

Redner, H. (2004). Conserving cultures: technology, globalization, and the future of local cultures. Rowman \& Littlefield Publishers, Inc.

Rohm, A. J., Milne, G. R., \& McDonald, M. (2006). A mixed-method approach for developing market segmentation typologies in the sports industry. Sport Marketing Quarterly, 15(1), 29-39.

Romney, M., \& Johnson, R. G. (2020). Show me a story: narrative, image, and audience engagement on sports network Instagram accounts. Information, Communication and Society, 23(1), 94-109. https://doi.org/10.1080/1369118X.2018.1486868

Seippel, Ø. (2017). Sports and nationalism in a globalized world. International Journal of Sociology, 47(1), 43-61. https://doi.org/10.1080/00207659.2017.1264835

Seippel, Ø., Dalen, H. B., Sandvik, M. R., \& Solstad, G. M. (2018). From political sports to sports politics: on political mobilization of sports issues. International Journal of Sport Policy and Politics, 10(4), 669-686. https://doi.org/10.1080/19406940.2018.1501404

Shamir, B., \& Eilam, G. (2005). "What's your story?" a life-stories approach to authentic leadership development. The Leadership Quarterly, 16(3), 395-417. https://doi.org/10.1016/j.leaqua.2005.03.005

Shilling, Ch. (2005). The body in culture, technology and society. Series: Theory, Culture and Society. M. Featherstone (Ed.). SAGE Publications.

Skinner, J., Smith, A. C. T., \& Swanson, S. (2018). Fostering innovative cultures in sport: leadership, innovation and change. Springer International Publishing AG.

Sohn, K., Canbolat, M. S., \& Gardner, J. T. (2017). How should marketers deal with growth pattern changes in viral marketing campaigns? International Journal of Internet Marketing and Advertising, 11(2), 137-157. https://doi.org/10.1504/IJIMA.2017.084081

Sowell, Th. (1995). The vision of the anointed: self-congratulation as a basis for social policy. Basic Books.

Sport Accord. (2010). Definition of sport. https://web.archive.org/web/20111028112912/http://www. sportaccord.com/en/members/index.php?idIndex=32\&idContent $=14881$

St.Pierre, M., Hofinger, G., \& Simon, R. (2016). Crisis management in acute care settings: human factors and team psychology in a high-stakes environment. Springer International Publishing.

Stoldt, G. C., Dittmore, S. W., \& Branvold, S. E. (2012). Sport public relations: managing stakeholder communication. Series: Library of Congress Cataloging-In-Publication Data. Human Kinetics.

Tkaczyk, J., \& Krzyżanowska, M. (2013). Understanding customers in creative industries. International Journal of Sales, Retailing and Marketing, 2(2), 58-67.

Trail, G. T., Fink, J. S., \& Anderson, D. F. (2003). Sport spectator consumption behavior. Sport Marketing Quarterly, 12(1), 8-17.

Trail, G. T., \& James, J. D. (2001). The motivation scale for sport consumption: assessment of the scale's psychometric properties. Journal of Sport Behavior, 24(1), 108-127.

United Nations. (2003). Sport for development and peace: towards achieving the millennium development goals. Report from the United Nations Inter-Agency Task Force on Sport for Development and Peace. https://www.unicef.org/sports/reportE.pdf 
Wheaton, B., \& Thorpe, H. (2019). Action sport media consumption trends across generations: exploring the olympic audience and the impact of action sports inclusion. Communication \& Sport, 7(4), 415-445. https://doi.org/10.1177/2167479518780410

Yousaf, A., Bashir, M., \& Mishra, A. (2020). Revisiting spectator-based sports team reputation: strategic implications for team managers. Corporate Reputation Review, 23(1), 1-12. https://doi.org/10.1057/s41299-019-00068-y

\title{
SPORTO IR SPORTO KOMUNIKACIJOS ANALIZE் KŪRYBINIŲ INDUSTRIJŲ KONTEKSTE
}

\author{
Stanislav DADELO
}

\begin{abstract}
Santrauka
Sporto reiškinio atsiradimas siejamas su visuomenès komunikacijos procesais. Sportas - tai socialinis reiškinys, kuris integraliai sprendžia daugybę skirtingų uždavinių. Sporto integralumas ir populiarumas paskatino sporto industrijos atsiradimą ir plètrą. Sporto industrija integruoja visų žmogaus veiklos rūšių sritis, vykstant visuomenès socialinei raidai ir technologijų plètrai, keičiasi ir sporto industrija. Pagrindinis jos uždavinys - tenkinti ịvairaus lygmens visuomenès poreikius (asmens, grupès, bendruomenès, valstybès, tarptautinius). Sporto reiškinys padeda spręsti ir asmenybės augimo uždavinius. Atlikta sporto ir sporto industrijos pagrindų analizė leidžia ịvertinti sporto industrijos svarbą ir plètros gaires. Sporto reiškinys ir jo generuojama industrija reikalauja plačių integralių tyrimų sujungiant iš pirmo žvilgsnio nesusiejamas sritis (edukaciją, fiziologiją, psichologiją, teisę, ekonomiką, komunikaciją, kultūrą, technologijas ir t. t.).
\end{abstract}

Reikšminiai žodžiai: turinys, plètra, sporto integralumas, sąsajos, visuomenès poreikiai, vertybès. 